\title{
Two randomised phase II trials of subcutaneous interleukin-2 and histamine dihydrochloride in patients with metastatic renal cell
}

\section{carcinoma}

\author{
F Donskov*,', M Middleton ${ }^{2,5}$, K Fode', P Meldgaard', W Mansoor², J Lawrance ${ }^{4}$, N Thatcher', H Nellemann ${ }^{3}$ \\ and $\mathbf{H}$ von der Maase'
}

'Department of Oncology, Aarhus University Hospital, Nørrebrogade 44, 8000 Aarhus C, Denmark; ${ }^{2}$ Department of Medical Oncology, Christie Hospital, Manchester, UK; ${ }^{3}$ Department of Radiology, Aarhus University Hospital, Aarhus, Denmark; ${ }^{4}$ Department of Radiology, Christie Hospital, Manchester, UK

\begin{abstract}
Histamine inhibits formation and release of phagocyte-derived reactive oxygen species, and thereby protects natural killer and T cells against oxidative damage. Thus, the addition of histamine may potentially improve the efficacy of interleukin-2 (IL-2). Two randomised phase II trials of IL-2 with or without histamine dihydrochloride (HDC) in patients with metastatic renal cell carcinoma (mRCC) were run in parallel. A total of 41 patients were included in Manchester, UK and 63 in Aarhus, Denmark. The selfadministered, outpatient regimen included IL-2 as a fixed dose, I 8 MIU s.c. once daily, 5 days per week for 3 weeks followed by 2 weeks rest. Histamine dihydrochloride was added twice daily, $1.0 \mathrm{mg}$ s.c., concomitantly with IL-2. A maximum of four cycles were given. The Danish study showed a statistically significant I-year survival benefit ( 76 vs $47 \%, P=0.03$ ), a trend towards benefit in both median survival ( 8.3 vs II.4 months, $P=0.07$ ), time to PD (4.5 vs 2.2 months, $P=0.13)$ and clinical benefit $(C R+P R+S D)(58$ vs $37 \%, P=0.10$ ) in favour of IL-2/HDC, whereas the UK study was negative for all end points. Only three patients had grade 4 toxicity; however, two were fatal. A randomised phase III trial is warranted to clarify the potential role of adding histamine to IL-2 in $\mathrm{mRCC}$. British Journal of Cancer (2005) 93, 757-762. doi: I 0.1038/sj.bjc.6602768 www.bjcancer.com
\end{abstract}

Published online 30 August 2005

(C) 2005 Cancer Research UK

Keywords: histamine dihydrochloride; interleukin-2; renal cell carcinoma; randomised; oxidative stress

Patients with untreated metastatic renal cell carcinoma (mRCC) have a poor prognosis with a median survival of about 8 months (Haas et al, 1993), and only 10\% survive beyond 3 years (Elson et al, 1988). The results remain poor because mRCC is highly refractory to therapy, including radiation, hormones and chemotherapy (Motzer and Russo, 2000). However, immunological manipulation using interleukin-2 (IL-2) mediate durable tumour regression in 5$10 \%$ of patients lasting 5 and 10 years, and this subgroup of patients are probably cured (Bordin et al, 2000; Fisher et al, 2000; Negrier et al, 2000; Atzpodien et al, 2002). Despite this important improvement, the vast majority of patients will die of their disease and therefore novel treatment strategies or identification of new agents with better antitumour activity remain a high priority.

The explanation for the low level of treatment success following IL-2 based immunotherapy is probably extremely complex. However, the new paradigm of tumours arising and persisting in the setting of chronic inflammation (Pollard, 2004; Vakkila and Lotze, 2004) may represent one of several factors of importance for treatment failure. Among macrophage and neutrophil products, reactive oxygen species (ROS) may not only induce genomic instability (O’Byrne and Dalgleish, 2001) but also damage

\footnotetext{
*Correspondence: Dr F Donskov; E-mail: fd@microbiology.au.dk

${ }^{5}$ Current address: Cancer Research UK Medical Oncology Unit, Churchill Hospital, Oxford, UK

Received I5 June 2005; revised 25 July 2005; accepted 2 August 2005; published online 30 August 2005
}

antitumour immune effector cells, especially natural killer (NK) and T cells (Seaman et al, 1982; Hellstrand et al, 1994a; Hansson et al, 1996a). Intratumoural macrophages isolated from melanoma metastases inhibit NK cell function by the release of ROS (Kono et al, 1996). Intratumoral NK and T cells isolated from mRCC show sign of oxidative damage (Finke et al, 1993; Tartour et al, 1995). Interleukin-2 cannot activate NK cells in vitro in the presence of monocytes or macrophages (Hellstrand and Hermodsson, 1990). However, histamine dihydrochloride (HDC), acting via $\mathrm{H}_{2}$-type receptors on phagocytes, has been shown to inhibit the ROSproduction by phagocytes, and therefore protects NK and T cells from inhibition and apoptosis. Reversal of this oxidative suppression of NK and T cells may, thus, be important to enhance the immune response with IL-2 (Hellstrand et al, 2000; Hellstrand, 2002). We have explored this potential mechanism clinically in the present two randomised phase II trials of IL-2 with or without HDC in mRCC.

\section{PATIENTS AND METHODS}

\section{Aims and objectives}

Two parallel randomised, prospective, open-label, phase II trials were conducted, one in Manchester, UK and one in Aarhus, Denmark to compare IL-2/HDC $v s$ IL-2-alone as first-line treatment for mRCC. The two studies had a similar study design and patient selection criteria. Primary objectives were response 
and toxicity. Secondary objectives were time to disease progression, overall survival and 1-year survival.

\section{Patients}

The trials were approved by the local ethics committees and the National Medical Agencies. All subjects gave written informed consent before inclusion. Main inclusion criteria were inoperable, bidimensionally measurable, histologically confirmed mRCC, 18-75 years of age, Karnofsky performance status $\geqslant 70$, life expectancy $>3$ months; haemoglobin $>10.0 \mathrm{~g} \mathrm{dl}^{-1}$; white blood cell count $>3.0 \times 10^{9}$ cells $^{-1}$; platelet count $>100 \times 10^{9} 1^{-1}$; partial thromboplastin time and creatinine $<1.5$ times the upper limit of normal; serum bilirubin $<1.25$ the upper limit of normal. Main exclusion criteria were brain metastasis, central nervous system disorders, psychiatric disability, pheochromocytoma, glaucoma, abnormal cardiac function, asthma or systemic allergic reaction treated within the last 5 years, bleeding ulcer disease, infections requiring antibiotics, prior chemotherapy, immunotherapy or extensive radiotherapy in the last 4 weeks and ongoing active malignancies except in situ carcinoma of the cervix or localised carcinomas of the skin.

Beta-blocker medications, $\mathrm{H}_{2}$ receptor antagonists and steroidal medications were not allowed. $\mathrm{H}_{1}$ receptor antagonists were allowed $<5$ days to treat skin itching.

\section{Treatment}

Patients were consecutively randomised by center to receive either IL-2/HDC or IL-2 alone. One cycle consisted of IL-2 (Aldesleukin, rIL-2, Proleukin ${ }^{\circledR}$, Chiron, The Netherlands) as a fixed dose, 18 MIU s.c. once daily, 5 days per week for 3 weeks followed by 2 weeks rest. HDC (Ceplene ${ }^{\mathrm{TM}}$, supplied by Maxim Pharmaceuticals Inc, San Diego, USA) $1.0 \mathrm{mg}$, was added twice daily by a slow 20 min injection s.c., concomitantly with IL-2. Patients were evaluated for objective response every two cycles. A maximum of four treatment cycles was given.

Due to the outpatient nature of this protocol, patients received instruction, guidance and monitoring during the first days of IL-2 and histamine injections before self-administration at home. Only a few subjects required home care nursing for the injections.

\section{Evaluation of patients}

Toxicity evaluation, physical examination and laboratory tests were performed every 5 weeks. Patients were evaluated for response after two and four cycles, if appropriate, and thereafter every third month until progressive disease (PD) was observed. Responses were reconfirmed after at least 4 weeks.

Objective response was defined according to the standard WHO criteria (Miller et al, 1981): (a) complete response (CR), defined as total disappearance of all clinical disease; (b) partial response (PR), defined as a reduction of more than $50 \%$ in the bidimensionally product diameter; (c) stable disease (SD), defined as a reduction of less than $50 \%$ or an increase in size of less than 25\%; and (d) PD, defined as an increase in size of more than $25 \%$ in the bidimensionally product diameter or appearance of new lesions.

\section{Dose modifications}

Toxicity was graded according to NCI common toxicity criteria, version 2.0. In general, no dose reduction of either study drug was done in case of grade 1 or 2 toxicity. In case of grade 3 or 4 toxicity, treatment was interrupted until toxicity returned to grade 1 or less or grade 2 or less. In most cases, IL-2 was then restarted at the $50 \%$ dose level and histamine at the $100 \%$ dose level.

\section{Management of toxicity}

All patients received the following as needed to minimise toxicity: paracetamol, metoclopramide, ondansetron, loperamide, omeprazole, furosemide or mucopolysaccharidepolysulphate.

\section{Follow-up}

Responses were evaluated every 3 months until PD. Patients were followed for survival every 3 months until death. No patients were lost to follow-up.

\section{Statistical methods}

Treatment differences in response rates and other proportions were compared using Fisher's exact test. Time to PD was measured from first day of treatment until disease progression. Overall survival was measured from first day of treatment until death or last follow-up evaluation. The cumulated survival rate was estimated by the Kaplan-Meier method. The log-rank test was used to analyse survival differences among subgroups of patients. All calculations were performed using SPSS 11.0 statistical software. The survival data were updated 14 April 2005.

\section{RESULTS}

Between June 1999 and August 2001, 41 patients were enrolled at the Department of Medical Oncology, Christie Hospital, Manchester, UK. Between August 2000 and August 2002, 63 patients were enrolled at the Department of Oncology, Aarhus, Denmark. The median follow-up time was 55 and 43 months, respectively, and the minimum length of follow-up 49 and 32 months, respectively. Separate analyses were carried out for the two studies as the trials were run independently. All patients met the eligibility criteria and were evaluable for toxicity. Number of patients receiving the planned drug dose was not significantly different between treatment arms in either of the two centres. Two patients in Manchester and four patients in Aarhus were nonevaluable for response as they stopped treatment within the first treatment cycle due to toxicity without signs of PD.

Table 1 lists baseline patient characteristics for the two patient populations. Patient characteristics were generally well balanced across treatment arms in the two studies, although slightly more Danish patients on the IL-2 arm had liver metastases $(P=0.17)$ and slightly more Danish patients on the IL-2/HDC arm were males $(P=0.10)$ (Table 1$)$. When comparing the two study centres, it was noted that the UK patients more often had lung metastasis only (13/41 vs 2/63) than the Danish patients. More Danish patients had their primary kidney tumour in situ (26/63 vs 7/41), had higher frequency of lymph node metastases (38/63 vs 14/41), bone metastases $(22 / 63 v s$ 4/41) and number of disease sites (three or more) (41/63 vs 10/41) than the UK patients.

\section{Tumour response}

Based on an intention-to-treat analysis, overall response rates were not statistically significantly different between treatment groups (Table 2). However, for the Danish patients, a higher percentage of clinical benefit $(\mathrm{CR}+\mathrm{PR}+\mathrm{SD})$ was noted in the IL-2/HDC group compared with the IL-2-alone group (58 vs 37\%, respectively). This difference was of borderline significance $(P=0.10)$. Response rates were identical in the two treatment groups in the UK study (Table 2).

\section{Survival}

Kaplan-Meier survival distribution curves for the Danish patients $(n=63)$ demonstrated a trend for improved survival for the IL-2 
Table I Baseline patient characteristics

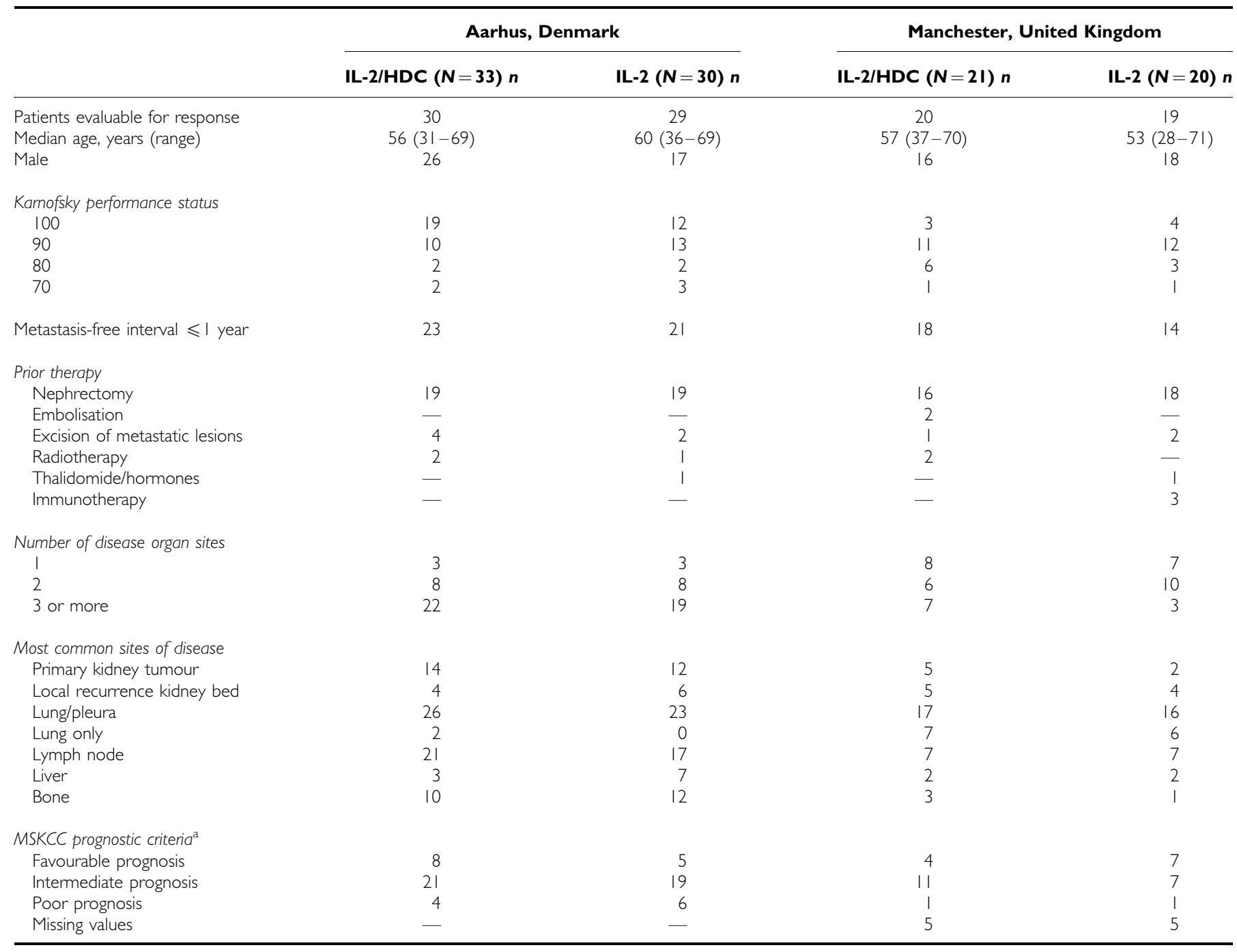

àemorial Sloan-Kettering Cancer Center. J Clin Oncol 1999; I7: 2530-2540.

Table 2 Response to treatment

\begin{tabular}{|c|c|c|c|c|c|c|}
\hline & \multicolumn{3}{|c|}{ Aarhus, Denmark } & \multicolumn{3}{|c|}{ Manchester, United Kingdom } \\
\hline & $\begin{array}{c}\text { IL-2/HDC }(\mathrm{N}=33) \\
n(\%)\end{array}$ & $\begin{array}{c}\text { IL-2 }(N=30) \\
n(\%)\end{array}$ & $P$ & $\begin{array}{c}\text { IL-2/HDC }(\mathbf{N}=2 \mathbf{I}) \\
n(\%)\end{array}$ & $\begin{array}{c}\text { IL-2 }(\mathbf{N}=\mathbf{2 0}) \\
n(\%)\end{array}$ & $P$ \\
\hline Evaluable for response & 30 & 29 & & 20 & 19 & \\
\hline$C R$ & 2 & 1 & & 0 & 0 & \\
\hline$P R$ & 2 & 0 & & 3 & 3 & \\
\hline SD & 15 & 10 & & 9 & 8 & \\
\hline Clinical benefit (ITT) & $19(58)$ & $11(37)$ & 0.10 & $12(57)$ & $11(55)$ & 1.0 \\
\hline
\end{tabular}

$\mathrm{CR}=$ complete response; $\mathrm{PR}=$ partial response; $\mathrm{SD}=$ stable disease; $\mathrm{PD}=$ progressive disease; clinical benefit $=\mathrm{CR}+\mathrm{PR}+\mathrm{SD} ; \mathrm{ITT}=$ intention-to-treat analysis.

plus HDC group compared with the IL-2-alone group (Figure 1). Thus, median survival was improved from 11.4 months (IL-2) to 18.3 months (IL-2/HDC). This difference was of borderline significance ( $\log$ rank $P=0.07$ ) (hazard ratio $0.61,95 \%$ CI: $0.36-$ 1.05) (Figure 1). The 1-year survival rate was statistically significantly improved from $47 \%$ for the IL-2-alone group to $76 \%$ for the IL-2 plus HDC group $(P=0.03)$. However, Kaplan-
Meier survival curves for the UK patients $(n=41)$ were almost identical with no differences in median survival (IL-2, 12.9 months; IL-2/HDC, 13.2 months, $P=0.6)$ or in the 1 -year survival rate (IL-2, 55\%; IL-2/HDC, 52\%) (Figure 1).

At the time of analysis, 36 and 53 patients in the UK and the Danish study, respectively, had died. Thus, the event rate was 88 and $84 \%$, respectively. 

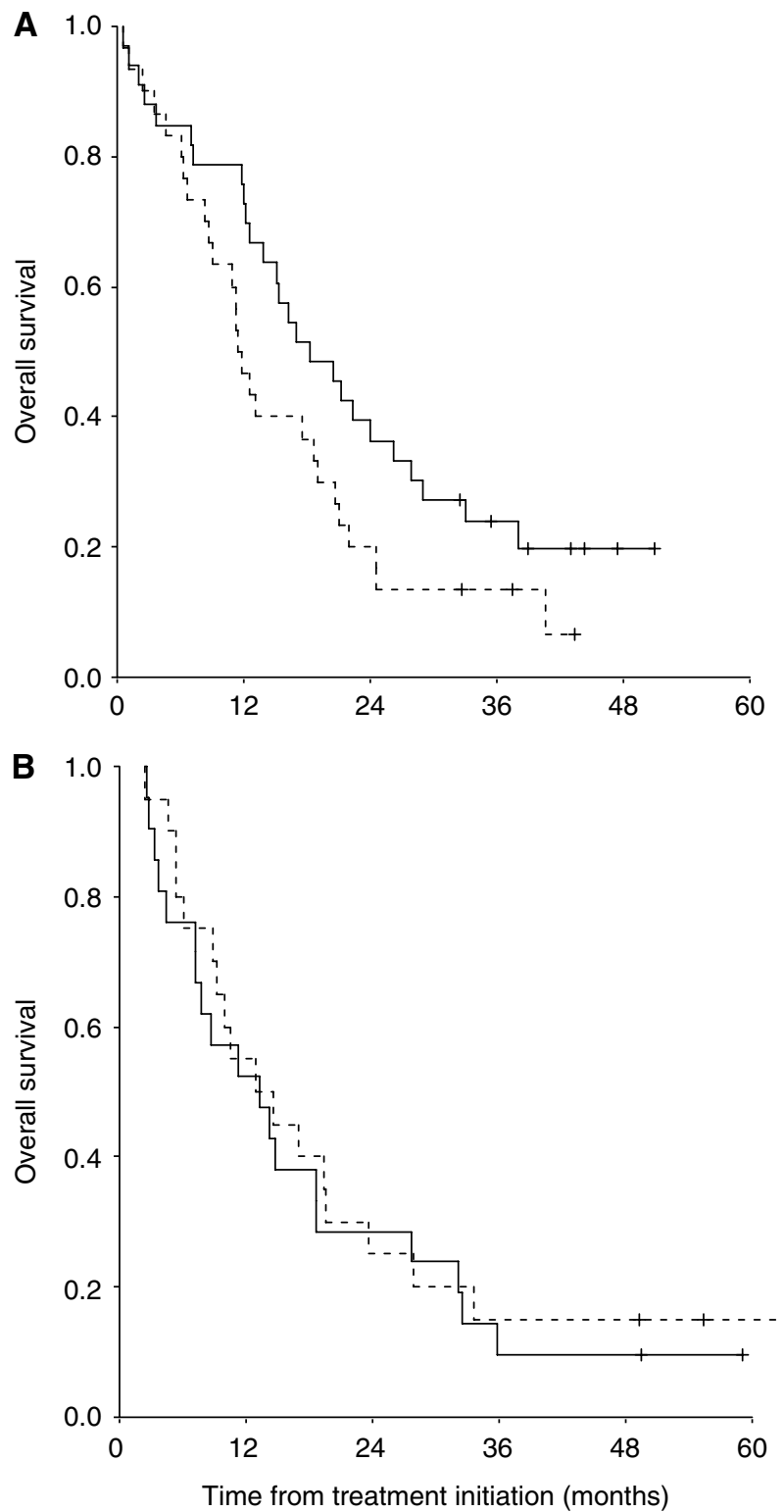

Figure I Kaplan-Meier estimates for overall survival of IL-2 plus histamine (-) vs IL-2 alone (- - ). Tick marks represent last date of followup. (A) Aarhus, $n=63$, (B) Manchester, $n=41$.

\section{Time to PD}

Time to PD was not statistically significantly different for the two treatment groups in either of the two studies (Figure 2). In the Danish study, median time to PD was 2.2 months in the IL-2-alone group and median 4.5 months in the IL-2 plus HDC group $(P=0.13)$, whereas time to $\mathrm{PD}$ was identical in the two treatment groups in the UK study (Figure 2). At the time of analysis, only one patient had not progressed, giving a censoring rate of $1 \%$ in total for the two studies.

\section{Toxicity}

At least $70 \%$ of patients received two cycles of treatment and at least $23 \%$ of patients received four cycles of treatment in the two studies. A total of 4500 histamine injections were given as selfadministration at home without medical supervision. In general, toxic effects were minor to moderate. All patients had at least one toxic side effect. Table 3 lists grade $3 / 4$ toxicity to treatment. There was generally more reported toxicity among the Danish patients
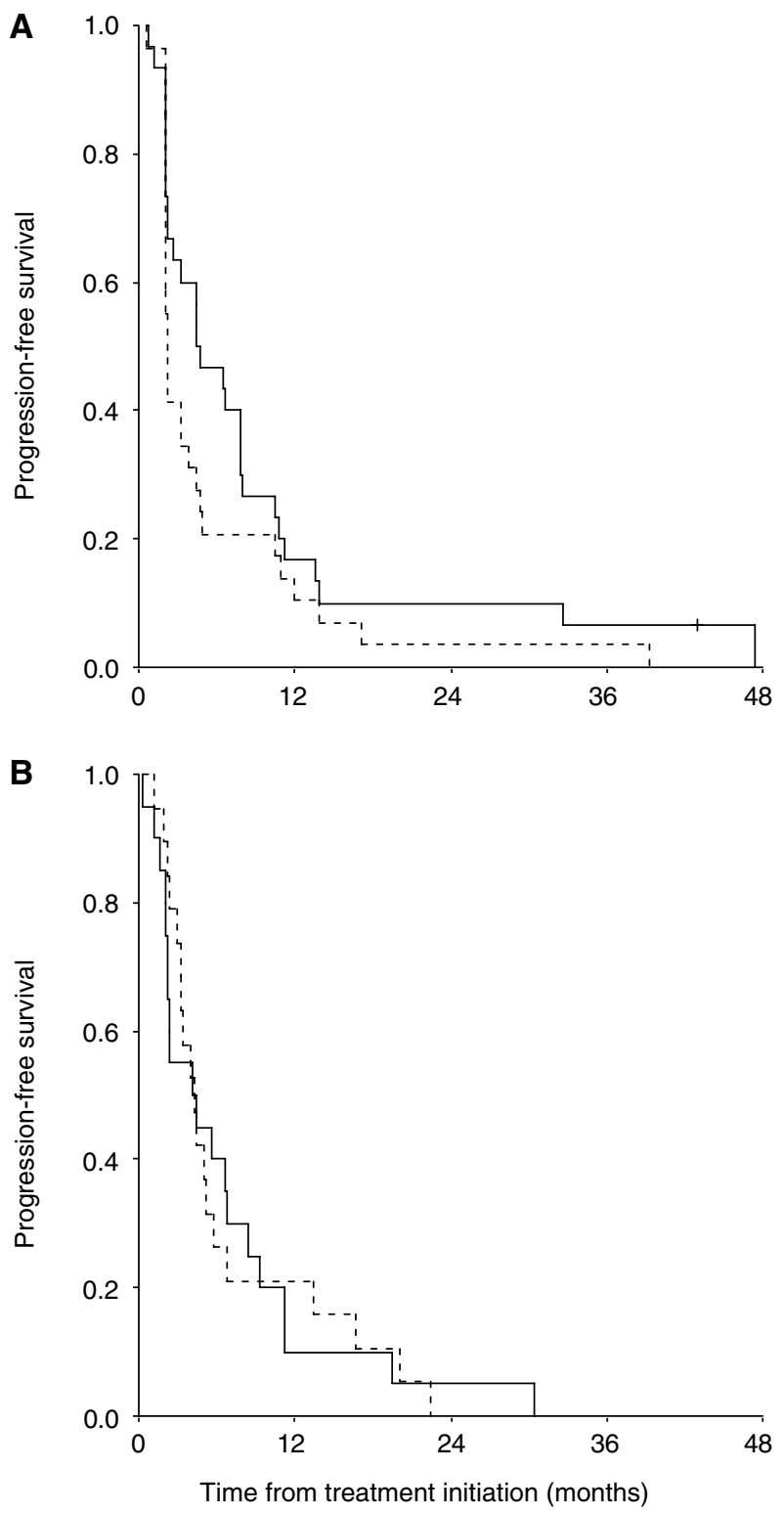

Figure 2 Kaplan-Meier estimates for progression-free survival of IL-2 plus histamine (-) vs IL-2 alone (-- -). (A) Aarhus, $n=63$, (B) Manchester, $n=41$.

compared with the UK patients. Concerning nausea and vomiting, the toxicity was more pronounced in the UK study. However, toxicity was not significantly different for IL-2-alone compared with IL-2 plus HDC in either of the studies. In total, only three of the 104 patients had grade 4 toxicity (lethargy, Escherichia coli sepsis and thrombocytopenia/bowel infarction, respectively). These three patients received IL-2/HDC and two of the episodes were fatal. One patient died due to septicaemia, which was considered unrelated to the study drug medication. The other patient died due to thrombocytopenia/bowel infarction and this death was possibly related to treatment.

\section{DISCUSSION}

Since its introduction to the clinic in 1985, IL-2 remains the only established cytokine approved by the US Food and Drug Administration for the treatment of mRCC. Despite 20 years of investigations, no combination therapy has proved better than IL-2 
Table 3 Grade 3 or 4 toxicity to treatment

\begin{tabular}{|c|c|c|c|c|}
\hline & \multicolumn{2}{|c|}{ Aarhus, Denmark } & \multicolumn{2}{|c|}{$\begin{array}{c}\text { Manchester, United } \\
\text { Kingdom }\end{array}$} \\
\hline & $\begin{array}{l}\text { IL-2/HDC } \\
(N=33)\end{array}$ & $\begin{array}{c}\text { IL-2 } \\
(N=30)\end{array}$ & $\begin{array}{l}\text { IL-2/HDC } \\
(N=2 \text { I })\end{array}$ & $\begin{array}{c}\text { IL-2 } \\
(N=20)\end{array}$ \\
\hline & $\%$ & $\%$ & $\%$ & $\%$ \\
\hline Nausea & & & 14 & \\
\hline Vomiting & & & 5 & 5 \\
\hline Diarrhoea & & 3 & & \\
\hline Stomatitis & & & & 5 \\
\hline Weight loss/anorexia & & 3 & & \\
\hline Dyspnea & 6 & 13 & 5 & \\
\hline Cough & & 7 & & \\
\hline Bronchospasm & & 3 & & 5 \\
\hline Dehydration & & 3 & & \\
\hline Lethargy & 18 & 20 & 10 & 10 \\
\hline $\begin{array}{l}\text { Local injection site } \\
\text { reaction }\end{array}$ & 9 & 3 & & \\
\hline Urticaria/facial swelling & & & 5 & 5 \\
\hline Flu-like symptoms & & 7 & 10 & 5 \\
\hline Confusion/memory loss & 6 & 7 & & \\
\hline Hypotension & 3 & & & \\
\hline Headache & & & 5 & \\
\hline Oedema & & & 5 & \\
\hline Tremor & 3 & & & \\
\hline Pain & & 3 & & \\
\hline Creatinin rise & & 3 & & \\
\hline Hyperkalemia & 3 & 3 & & \\
\hline Others & 6 & & & \\
\hline At least one SAE & 49 & 43 & 19 & 35 \\
\hline
\end{tabular}

Worst grade $3 / 4$ related to treatment according to $\mathrm{NCl}$ common toxicity criteria version 2.0. SAE = severe adverse event

treatment alone in terms of long-term survival (Negrier et al, 1998; McDermott et al, 2005).

Histamine dihydrochloride as an adjunct to IL-2 is an example of translational research from basic biology to clinical trials. A large number of in vitro and in vivo observations from independent laboratories have supported the observation of oxidative suppression of $\mathrm{NK}$ and $\mathrm{T}$ cells by phagocytes (i.e. monocytes, macrophages and neutrophils) (Seaman et al, 1982; Finke et al, 1993; Tartour et al, 1995; Hansson et al, 1996a; Kono et al, 1996; Saio et al, 2001). Hellstrand and co-workers have demonstrated that histamine protects $\mathrm{NK}$ and $\mathrm{T}$ cells against oxygen radical-induced dysfunction and apoptosis by specifically blocking the formation and release of hydrogen peroxide $\left(\mathrm{H}_{2} \mathrm{O}_{2}\right)$ from phagocytes, and moreover, maintains the activation of NK and T cells by IL-2 (Hellstrand and Hermodsson, 1986, 1990, 1991; Hellstrand et al, 1990, 1994a,b; Asea et al, 1996; Hansson et al, 1996b, 1999). This potential mechanism has been explored clinically in acute myelogenous leukaemia (Brune and Hellstrand, 1996), chronic hepatitis C (Lurie et al, 2002), multiple myeloma (Mellqvist et al, 1999), metastatic melanoma (Agarwala et al, 2002, 2004; Schmidt et al, 2002) and mRCC (Donskov et al, 2002).

We introduced histamine in mRCC in combination with lowdose IL-2 and IFN- $\alpha$ (Donskov et al, 2002). In parallel with the clinical trial, we obtained serial blood samples and tumour biopsies, searching for a potential histamine effect in situ

\section{REFERENCES}

Agarwala SS, Glaspy J, O'Day SJ, Mitchell M, Gutheil J, Whitman E, Gonzalez R, Hersh E, Feun L, Belt R, Meyskens F, Hellstrand K, Wood D, Kirkwood JM, Gehlsen KR, Naredi P (2002) Results from a randomized phase III study comparing combined treatment with histamine dihydrochloride plus interleukin-2 vs interleukin-2 alone in patients with metastatic melanoma. J Clin Oncol 20: 125-133
(Donskov et al, 2004). However, in that low-dose schedule of IL-2 and IFN- $\alpha$, histamine did not appear to add efficacy with respect to response (Donskov et al, 2002). Moreover, no discernable differences in the examined immunologic parameters in blood and tumour tissue could be detected between histamineand nonhistamine-treated patients (Donskov et al, 2004).

However, the question of whether histamine might improve efficacy with higher doses of IL-2 formed the basis for the present studies representing the first randomised trials in mRCC evaluating the efficacy and safety of subcutaneous IL-2 in combination with HDC. Thus, in the present study, we have doubled the dose of IL-2 compared to that in our first IL-2/IFN/histamine-study and the applied IL-2 dose can be considered to be an intermediate dose level. Protocol criteria were similar in the two studies. However, the Danish patients had a significantly greater disease burden than UK patients. The outcome of the individual studies differed as the Danish study showed a statistically significant 1-year survival benefit and a trend towards benefit in both overall survival and clinical benefit $(C R+P R+S D)$ in favour of IL-2/HDC, whereas the UK study was negative for all end points. This means that the potential effect of histamine was only indicated in the Danish study and by that in the group of patients with the worse prognosis. The explanation for this difference in the outcome of the two trials is unclear, but it should be emphasised that the different outcome may have been obtained by pure chance.

In the Danish patients, we also assessed the oxidative stress hypothesis by monitoring cells of potential benefit (i.e. NK and $\mathrm{T}$ cells) and cells of potential harm (i.e. monocytes/macrophages and neutrophils) simultaneously in blood and tumour tissue, before and during treatment. These assays provide compelling evidence for circulating monocytes and neutrophils as powerful negative prognostic factors for IL-2 based immunotherapy and establish a biological rationale for the addition of histamine to IL-2 in mRCC. Thus, targeting $\mathrm{H}_{2} \mathrm{O}_{2}$ by histamine seems to enhance the antitumour activity of IL-2 in situ in a subgroup of patients with low monocytes/neutrophils or high NK cells. These results will be published separately.

Toxicity was in general manageable in an outpatient setting, although we observed one possible toxic death. Adverse events noted in patients treated with the combination of IL-2 and histamine were almost similar in type and frequency as toxicities in patients treated with IL-2 alone.

In conclusion, the outcome of the individual studies differed as the Danish study showed a trend towards benefit in favour of IL-2/HDC, whereas the UK study was negative for all end points. A randomised phase III trial is warranted to clarify the potential role of adding histamine to IL-2 in mRCC.

\section{ACKNOWLEDGEMENTS}

Staff members at the Departments of Oncology are acknowledged for their careful management of the patients. Lynn Lomax, Jackie Hodgetts and Linda Ashcroft are acknowledged for help with the conduct of the study. This work was supported by grants from the Danish Research Council, Max and Inger Woerzner Foundation and The Radium Centre Research Foundation. Maxim Pharmaceuticals kindly supported both studies financially.
Agarwala SS, Hellstrand K, Gehlsen K, Naredi P (2004) Immunotherapy with histamine and interleukin 2 in malignant melanoma with liver metastasis. Cancer Immunol Immunother 53: 840-841

Asea A, Hermodsson S, Hellstrand K (1996) Histaminergic regulation of natural killer cell-mediated clearance of tumour cells in mice. Scand J Immunol 43: 9-15 
Atzpodien J, Hoffmann R, Franzke M, Stief C, Wandert T, Reitz M (2002) Thirteen-year, long-term efficacy of interferon 2alpha and interleukin 2-based home therapy in patients with advanced renal cell carcinoma. Cancer 95: 1045 - 1050

Bordin V, Giani L, Meregalli S, Bukovec R, Vaghi MM, Mandala M, Paolorossi F, Ardizzoia A, Tancini G, Barni S, Frigerio F, Fumagalli L, Bordoni A, Valsuani G, Di Felice G, Lissoni P (2000) Five-year survival results of subcutaneous low-dose immunotherapy with interleukin-2 alone in metastatic renal cell cancer patients. Urol Int 64: 3-8

Brune M, Hellstrand K (1996) Remission maintenance therapy with histamine and interleukin-2 in acute myelogenous leukaemia. $\mathrm{Br} J$ Haematol 92: 620-626

Donskov F, Bennedsgaard KM, Hokland M, Marcussen N, Fisker R, Madsen $\mathrm{HH}$, Fode K, von der Maase H (2004) Leukocyte orchestration in blood and tumour tissue following interleukin-2 based immunotherapy in metastatic renal cell carcinoma. Cancer Immunol Immunother 53: $729-739$

Donskov F, von der Maase H, Henriksson R, Stierner U, Wersall P, Nellemann H, Hellstrand K, Engman K, Naredi P (2002) Outpatient treatment with subcutaneous histamine dihydrochloride in combination with interleukin-2 and interferon-alpha in patients with metastatic renal cell carcinoma: results of an open single-armed multicentre phase II study. Ann Oncol 13: $441-449$

Elson PJ, Witte RS, Trump DL (1988) Prognostic factors for survival in patients with recurrent or metastatic renal cell carcinoma. Cancer Res 48 $7310-7313$

Finke JH, Zea AH, Stanley J, Longo DL, Mizoguchi H, Tubbs RR, Wiltrout RH, O'Shea JJ, Kudoh S, Klein E (1993) Loss of T-cell receptor zeta chain and p56lck in T-cells infiltrating human renal cell carcinoma. Cancer Res 53: $5613-5616$

Fisher RI, Rosenberg SA, Fyfe G (2000) Long-term survival update for highdose recombinant interleukin-2 in patients with renal cell carcinoma. Cancer J Sci Am 6(Suppl 1): S55-S57

Haas GP, Hillman GG, Redman BG, Pontes JE (1993) Immunotherapy of renal cell carcinoma. CA Cancer J Clin 43: 177 - 187

Hansson M, Asea A, Ersson U, Hermodsson S, Hellstrand K (1996a) Induction of apoptosis in NK cells by monocyte-derived reactive oxygen metabolites. J Immunol 156: $42-47$

Hansson M, Asea A, Hermodsson S, Hellstrand K (1996b) Histaminergic regulation of NK-cells: protection against monocyte-induced apoptosis. Scand J Immunol 44: 193-196

Hansson M, Hermodsson S, Brune M, Mellqvist UH, Naredi P, Betten A, Gehlsen KR, Hellstrand K (1999) Histamine protects $\mathrm{T}$ cells and natural killer cells against oxidative stress. J Interferon Cytokine Res 19: $1135-1144$

Hellstrand K (2002) Histamine in cancer immunotherapy: a preclinical background. Semin Oncol 29: 35-40

Hellstrand K, Asea A, Dahlgren C, Hermodsson S (1994a) Histaminergic regulation of NK cells. Role of monocyte-derived reactive oxygen metabolites. J Immunol 153: 4940-4947

Hellstrand K, Asea A, Hermodsson S (1990) Role of histamine in natural killer cell-mediated resistance against tumor cells. J Immunol 145: $4365-4370$

Hellstrand K, Asea A, Hermodsson S (1994b) Histaminergic regulation of antibody-dependent cellular cytotoxicity of granulocytes, monocytes, and natural killer cells. J Leukoc Biol 55: $392-397$

Hellstrand K, Brune M, Dahlgren C, Hansson M, Hermodsson S, Lindner P, Mellqvist UH, Naredi P (2000) Alleviating oxidative stress in cancer immunotherapy: a role for histamine? Med Oncol 17: 258-269

Hellstrand K, Hermodsson S (1986) Histamine H2-receptor-mediated regulation of human natural killer cell activity. J Immunol 137: 656-660
Hellstrand K, Hermodsson S (1990) Synergistic activation of human natural killer cell cytotoxicity by histamine and interleukin-2. Int Arch Allergy Appl Immunol 92: 379-389

Hellstrand K, Hermodsson S (1991) Cell-to-cell mediated inhibition of natural killer cell proliferation by monocytes and its regulation by histamine H2-receptors. Scand J Immunol 34: 741 - 752

Kono K, Salazar-Onfray F, Petersson M, Hansson J, Masucci G, Wasserman K, Nakazawa T, Anderson P, Kiessling R (1996) Hydrogen peroxide secreted by tumor-derived macrophages down-modulates signal-transducing zeta molecules and inhibits tumor-specific $\mathrm{T}$ cell- and natural killer cell-mediated cytotoxicity. Eur J Immunol 26: 1308-1313

Lurie Y, Nevens F, Aprosina ZG, Fedorova TA, Kalinin AV, Klimova EA Ilan Y, Maevskaya MV, Warnes TW, Yuschuk ND, Hellstrand K, Gehlsen KR (2002) A multicentre, randomized study to evaluate the safety and efficacy of histamine dihydrochloride and interferon-alpha-2b for the treatment of chronic hepatitis C. J Viral Hepat 9: 346-353

McDermott DF, Regan MM, Clark JI, Flaherty LE, Weiss GR, Logan TF, Kirkwood JM, Gordon MS, Sosman JA, Ernstoff MS, Tretter CP, Urba WJ, Smith JW, Margolin KA, Mier JW, Gollob JA, Dutcher JP, Atkins MB (2005) Randomized phase III trial of high-dose interleukin-2 vs subcutaneous interleukin-2 and interferon in patients with metastatic renal cell carcinoma. J Clin Oncol 23: $133-141$

Mellqvist UH, Wallhult E Brune M, Jacobsson S, Hellstrand K (1999) Histamine dihydrochloride, interleukin-2 and interferon-alfa in multiple myeloma. Int J Immunother 15: 125-130

Miller AB, Hoogstraten B, Staquet M, Winkler A (1981) Reporting results of cancer treatment. Cancer 47: 207-214

Motzer RJ, Russo P (2000) Systemic therapy for renal cell carcinoma. J Urol 163: $408-417$

Negrier S, Escudier B, Lasset C, Douillard JY, Savary J, Chevreau C, Ravaud A, Mercatello A, Peny J, Mousseau M, Philip T, Tursz T (1998) Recombinant human interleukin-2, recombinant human interferon alfa$2 \mathrm{a}$, or both in metastatic renal-cell carcinoma. Groupe Francais d'Immunotherapie. N Engl J Med 338: $1272-1278$

Negrier S, Maral J, Drevon M, Vinke J, Escudier B, Philip T (2000) Longterm follow-up of patients with metastatic renal cell carcinoma treated with intravenous recombinant interleukin-2 in Europe. Cancer J Sci Am 6(Suppl 1): S93 - S98

O'Byrne KJ, Dalgleish AG (2001) Chronic immune activation and inflammation as the cause of malignancy. Br J Cancer 85: 473-483

Pollard JW (2004) Tumour-educated macrophages promote tumour progression and metastasis. Nat Rev Cancer 4: 71-78

Saio M, Radoja S, Marino M, Frey AB (2001) Tumor-infiltrating macrophages induce apoptosis in activated CD8(+) $\mathrm{T}$ cells by a mechanism requiring cell contact and mediated by both the cellassociated form of TNF and nitric oxide. J Immunol 167: $5583-5593$

Schmidt H, Larsen S, Bastholt L, Fode K, Rytter C, von der Maase H (2002) A phase II study of outpatient subcutaneous histamine dihydrochloride, interleukin-2 and interferon-alpha in patients with metastatic melanoma. Ann Oncol 13: 1919-1924

Seaman WE, Gindhart TD, Blackman MA, Dalal B, Talal N, Werb Z (1982) Suppression of natural killing in vitro by monocytes and polymorphonuclear leukocytes: requirement for reactive metabolites of oxygen. J Clin Invest 69: $876-888$

Tartour E, Latour S, Mathiot C, Thiounn N, Mosseri V, Joyeux I, D’Enghien CD, Lee R, Debre B, Fridman WH (1995) Variable expression of CD3-zeta chain in tumor-infiltrating lymphocytes (TIL) derived from renal-cell carcinoma: relationship with TIL phenotype and function. Int J Cancer 63: $205-212$

Vakkila J, Lotze MT (2004) Inflammation and necrosis promote tumour growth. Nat Rev Immunol 4: 641-648 